\title{
The opinions of preschool teacher candidates on vocational and personal achievements from the drama lesson
}

\author{
Turan Çakı1 ${ }^{1}$
}

\begin{abstract}
The purpose of this study is to determine the opinion and attitudes of the preschool teacher candidates about the contribution of the drama lesson for their vocational and personal developments. The research sample consists of 62 students who take drama lessons in 2nd class in Department of Preschool Teaching of Teachers College of Sakarya University in 2014-2015. This study is actualized by descriptive research method that is one of the qualitative research techniques. Semi-structured interview form is used as the data collection tool. The content analysis is made by being interpreted the data collected. According to the results obtained, the teachers like the drama lessons when they took in university, and this lesson makes major contributions to their personal life and careers. It is confirmed at the end of this research that the attendees and the preschool teacher candidates notice the importance of the drama lesson at the right time and afterward as well. It is seen that the personal and vocational gains such as communication skills, verbal ability, empathy and social ability, body language, self-reliance, problem-solving, creativity, cognitive skills, awareness, learning by experience, psychomotor skills, taking responsibility skill are the qualifications that wanted to be gained by the students.
\end{abstract}

Keywords: Preschool; drama; teacher candidates; personal gain; vocational gain.

\section{Introduction}

Preschool education is an education period including the years from the birth of the child to the day he/she attends to the primary education process and plays a crucial role in the future of the children. Besides, physical, social, emotional, cognitive, language and self-care development of children are almost completely completed and the personal characteristics shape at the same time in this education process. It is seen that the preschool period is of capital importance when viewed from the aspects such as this time contains several critical processes till the children start to primary education and is a time that they have pretty high growth rate (Aral, Kandır, \& Yaşar, 2002).

The preschool child becomes skillful at developing the imagination, thinking freely, collaborating, creating cultural sensitivity in this process by solving problems in drama activities and the natural responses he/she gives as a result of the interaction with the group.

Therefore, the preschool education should be consciously actualized so as to reveal the abilities of the children by being considered the needs and the physical and emotional features of the children (Argun, 2012).

${ }^{1}$ Assist. Prof. Sakarya University, Faculty of Education, Department of Preschool Teaching, tcakir@sakarya.edu.tr 
Çakır, T. (2017). The opinions of preschool teacher candidates on vocational and personal achievements from the drama lesson. Journal of Human Sciences, 14(2), 2047-2060. doi:10.14687/jhs.v14i2.4616

Drama is a way of communication. Since the drama gets children adopt better-talking habit and brings language development that is the prime necessity, the child also becomes skillful at talking, thinking, telling and communicating with the others when he/she attends to the activities.

The person who will bring all these skills consciously is the preschool teachers. That's why being selected these teachers carefully, raised very well and their educational levels are crucial regarding the professional and social life (Oktay, 1993).

Traditional and rote learning prevent children from learning to share, their mental development, researching motivation. The game in preschool period is as important as eating and drinking for the child. The game provides the children to communicate with around, abreact, gain experience, have fun, relax and solve his/her problems.

Various methods and techniques must be used by teachers to bring required skills for children since the first years of their education lives. One of these methods is the drama.

The function of the drama in preschool education and training is efficient. Being used the drama as a way in education allows for the modern person to organize the social relations, know and present oneself and produce (Genç, 2003)

Drama is the playing and acting the real and the imaginative moments in life with a group managed by a leader by using the theater techniques in playful processes (Okvuran, 2003)

Drama is a new game-concentric formation improves the children and an education field all by itself. Drama is to animate an event, a game, a life by being benefited from the theater techniques, developed and lived as well. Drama involves a whole of features of a game. Drama provides a direct communication and interaction between the individuals.

Drama aims to operationalize the child and the individual to gain the abilities for finding his/her identity. The drama in education targets the person to be conscious of the own body, emotions and thoughts and goings-on around. In preschool education, the teacher guides for all drama studies and the study can be concluded by a game; but this end is not an absolute goal of the drama in education (Mc Caslin, 1990).

Drama means to learn with experience, watch, feel, try and do. Drama process ensures the individual to use his/her covered experiences, establish a bond between oneself and the role given and play it when she/he is good and ready by looking at the information of the individual and try to think different about what he/she does not know (Özdemir \& Üstündağ, 2007).

As a group activity, drama activates the feelings, imagination and imagery competence of the child to attend to the learning process. Drama is used to express a concept, thought, topic, event, life by the body signals and realize a status, design or thought (Morgül, 1999).

\section{Conceptual Framework}

\section{Preschool Education}

The preschool education is defined by the 14th National Education Council organized by Ministry of Education in 1993 as 'a training process within the basic education integrity that provides rich stimulator and environment probabilities suited for the development levels and the individual characteristics of the children between 0-72 month group, supports their physical, mental, emotional and social improvements, guides them perfectly in line with the cultural values of the society and also prepares them for the primary education (MNE, 1993)'. 
Çakır, T. (2017). The opinions of preschool teacher candidates on vocational and personal achievements from the drama lesson. Journal of Human Sciences, 14(2), 2047-2060. doi:10.14687/jhs.v14i2.4616

The preschool education is a development and training process plays a role in the birth of the child to the day he/she starts for the basic education when the mental and language developments almost entirely completed (Aral, Kandır, \& Yaşar, 2002). This period is a systematic education process for children when being laid the base of the positive edifying, discovered the creative sides, gained the self-confidence under the leadership of teachers and parents (Zembat, 1994). The training provided in this period guides for the next years of the child. Developing the potential of the human to the top level and making this beneficial can be actualized just by an educational environment full of rich stimulators in the childhood years (Çakır \& Oktay, 2004).

The preschool year is a process described by the development psychologists as the magical year. A large part of the behaviors obtained in this period shapes the personality structure, attitude, habit and value judgments of the individual in adulthood (Deniz \& Erözkan, 2016). The investment for the early childhood period is for the whole life of the children indeed. The return of the importance given to this term is gotten in entire life. If this period is neglected, the adverse effects may be seen on children and this negativity impacts all life. For this reason, it must be seized the opportunities in this period when the development of children is sensitive. The kids start for the primary education with the positive feelings about oneself and the possibility of success increase if they gain happy and meaningful experiences during the preschool training. The child knows oneself and is aware of his/her abilities (Yavuzer, 2013).

The preschool education teacher must have the same values for being gained the values mentioned above to the children. The drama lesson in preschool has mandatorily played a part in the programs of 'Preschool Education Teaching' of teachers college since 1997. Education and training become active and fruitful as a result of stimulating the senses by using drama in the education. It is observed that drama mediates to develop the imagery world, provide the esthetics improvement and socializing and awareness on ethic, gain the critical thinking and communication abilities and collaboration, believe in oneself, take decisions. In the preschool period, the teacher must know the developmental features of the age groups and consider this situation for the activity selection when studying with the children in drama activities (Adigüzel, 1993; Adı̈üzel, 1994; Adıgüzel, 2000; Adıüzel 2006).

The purpose of this lesson is to teach the description, historical development and relations of the drama with the other demonstrations and the plastic fields, the required cognitive process and abilities for attending of the drama activities, the qualifications of the drama teacher/leader, implementation phases of the drama, the features of the drama environment, special techniques used in drama, the contribution of the drama in preschool education for the development and training of the child, planing original drama activities. Besides, the other goals are; to bring theoretic knowledge and application skills and the theoretical studies on the field in the educational environments such as the class, drama saloon, painting and business studios, museum, etc in the half year weekly lesson plans by the collaboration with public, private, national and international institution, people, establishments and shareholders. Thus the teacher candidates become skillful at planning the drama activities in preschool education and applying as well (Köksal Akyol \& Çiftçibaşı, 2004).

The most severe interest of the child in preschool period is the game, most significant work is the game again. According to the researches conducted, the game is described as the learning, creating, gaining experience, communicating, expressing the feelings and the whole of the activities made freely, is the source of happiness, develops and entertains the child (Çakır, 2003). Drama is a learning tool enhances the artistic sensitivity and the conscious about oneself, others and the world and develops the imagination of each child. 
Çakır, T. (2017). The opinions of preschool teacher candidates on vocational and personal achievements from the drama lesson. Journal of Human Sciences, 14(2), 2047-2060. doi:10.14687/jhs.v14i2.4616

It is important to point out the activities during the drama applications. That's why acting the teacher quick and lively and talking so as to catch the attention avoid the distraction of the students (Önder, 2007).

It is also substantial to be the drama environment positive. There is need to create a trusted environment and win the trust if the attendees.

The preschool teacher must have a personality respects to the thoughts and the imagination of others and be a good observer to create a comfortable and sincere ambiance. Then this teacher should follow the children by considering all of them in drama group are different from each other and also the experiences may differ (McCaslin, 1984; Ömeroğlu, 2006).

Moreover, the teacher candidates who are aware of the importance of the drama can help children to solve problems, gain empathy and social skills by raising oneself in this field after being a teacher.

\section{Drama in Preschool Education}

Different definition and comments on drama in the literature by the doyens of the field are shown below.

As a modern and premise method, the drama helps to belong to a group, increase the communication and problem solving abilities and the sense of responsibility of being a member of a group, enable to activate the motions, phantasy, imagery ability, thought, potential competencies and the values of the children, individual or an old man by turning these into the funny and permanent educational processes. Drama is used to being understood a concept better and provided the person to express that idea by internalizing and thinking over (San, 1990; San, 1991; San, 1996).

Drama is a method ensures the person to develop all-around by placing oneself into someone else's position, be creative, active and eager in the learning process. There is need a reason, a necessity for children to learn something and put it into practice before forgetting. That is to say; the drama may be a tool for a teacher to create the necessity (Güneysu, 1991).

The child who is already in a tendency to move and attend to movable games activates his/her physical energy and communicates with the other kids in the group both verbal and non-verbal during the actions based on gross motor movements. He/she communes with the other children clubbily (Önder,2007; Karakaya, 2007).

In an education system, the goals of the drama in education as follows; to provide the creativity and aesthetic improvement, develop the moral and spiritual values, language and communication skills, imagination, feelings and thoughts, critical thinking and cooperation and decision making abilities, feel confident and allow for children to explore the ethical values (Mc Caslin, 1990).

It also needs to remember when we consider the drama in education as procedural that it has a goal such as teaching different subjects in training environment. Extending the interest of the children and teenagers, providing them to reach and look at the reality via imagery and understand rather than play are accepted some of these goals.

John Dewey is one of the first ones to study in drama field in education all over the world. Dewey worked on the drama theory in education. After that, Harriet Finlay-Johnson dealt with the subject of drama in education by his book called "The Dramatic Method of Teaching" in 1911. After Johnson, H. Caudwell Cook specified a model based on the principles of learning by experience, learning by practicing, be disposed and volunteer, learning by playing in his book called 'The Play Way' in 1917. Winifred Ward followed Cook by the books called 'Creative Dramatics' in 1930 and 'Playmaking for Children' in 1947. In 1960's, Dorothy Heathcote made a remarkable effort for being used the drama in education effectively, emphasized the effect of the 
Çakır, T. (2017). The opinions of preschool teacher candidates on vocational and personal achievements from the drama lesson. Journal of Human Sciences, 14(2), 2047-2060. doi:10.14687/jhs.v14i2.4616

drama on education and learning based on experiences and defined the drama as 'the practice of life' by believing this is an efficient technique for learning (San, 2006).

In our country, İsmail Hakkı Baltacıoğlu was the person who put the theater in schools by providing to being added a lesson under the name of 'historic representations' to the academic programs when he was the Minister of Education and published brochures called 'Education Method of School Representations' in 1915. How the school representations, shows, and dramas could be actualized, how the dramatization activities in classes could be conducted were stated on these brochures detailed and with instructions (Çoruh, 1943; Akyüz,1994; Board of Education,1340).

The representation (dramatic shows) were located in education and training principles Department of the primary school in the Primary School Program of Republic Period in 1926. In 1990's and 1940's, the dramatization activities in representative impersonation were actualized in the programs of primary and secondary schools. After, it is seen that there were talkings in Turkish lessons; drama, show, and theater work in extracurricular representation part. The book called 'Dramatization in Schools' written by Selahattin Çoruh in 1943 and the second edition published in 1950 has filled an important gap (MNE, 1936; MNE,1948; Morgül, 1999; Akyüz, 1999)

Dramatization was officially added to the secondary school programs by MNE (Ministry of National Education) in 1951. The art activities and drama studio works of Nevide Gökaydin who was the art educator and American specialists in Ankara in 1956 were filmed by MNE and film, radio and television center (FRTC) to benefit in educational institution (Erkunt, 1966 as cited in Levent, 1993)

It was started in the primary school program in 1962 that the impersonation by representation (dramatization) could be used to ensure the students express what they saw, read and thought via representation. The concept application samples about definition and application of the drama, pantomime, pastiches, dramatization in class and school theater were explained in the book published in the series of in-service training for teachers called 'Practical Dramatization' by Emin Özdemir in 1965. There are 50 pages chapter under the title of 'Children's Theatre' (Dramatization) in the book of Nimet Erkunt called 'Preschool Education' published as the six numbered publication of General Directorate of Primary Education (MNE, 1962; Erkunt, 1966 as cited in Levent, 1993)

It was mentioned in 1968 primary school program that some categories such as the fairy tale, novel, poem, representation, history could be dramatized on condition that considering the interest and necessities of the children. Also mentioned in the same program that the students could conduct activities as impersonation, game, representation and the dramatization works have an important place in verbal and written lecture. The applications also include representation, shows, pantomime, theater, and dramatization were continued in all the educational institutions within the scope of Turkish lesson programs and educational activities since 1970 till 1980 ( MEB, 1962; MEB,1968; MEB, 1999).

First of the Dramatization, dramatic and game-oriented activities were conducted in nursery school and kindergartens in 1980's; it was mentioned on the subject of 'drama' in Primary Education Schools Turkish Program published in the journal of Communiques that was 26th October 1981 dated and 2098 numbered. 'Drama Works in Education' occurred a significant and modern beginning which was started by Tamer Levent who is the actor and director of state theater with his teenage and young groups. The Art Education Platform was established by the attempts of Prof. Dr. Inci San who was the lecturer of Faculty of Educational Sciences of Ankara University and the works of Levent gain continuity and popularity with the contributions of this platform and took part in the literature under the name of creative drama. These applications 
Çakır, T. (2017). The opinions of preschool teacher candidates on vocational and personal achievements from the drama lesson. Journal of Human Sciences, 14(2), 2047-2060. doi:10.14687/jhs.v14i2.4616

raised several volunteer teachers and educators. First of 'Drama Seminar in International Education' was hold by the organizations of these two doyen names in 1985, after this date the drama has found place as a teaching method within the art education and the publishings and postgraduate thesis's stated to be written as well (Morgül, 1999; Vural \& Somers, 2012; Aytaş, 2008).

The academicians study about the subject, drama educator and leaders were invited from foreign with German Culture Association and San in 1990's; the drama lessons were started in military schools and police academies by being established the Ankara Modern Drama Association with the attempts of Inci San in the same year. In 1992, the in-service training education programs such as painting, music, drama for the preschool teacher candidates were planned and carried into periodical actions by the Minister of National Education and also with Ankara University's and Modern Drama Association's support. The Drama lesson was conducted by Head Council of Education and Morality of Minister of National Education in 1998 with the contributions and efforts of San. As a result of all these works, the drama lesson has been started as the elective course since 4th classes of all primary school programs. After being started to teach this lesson, the courses, seminar, and training programs were planned for the teachers. The 'Creative Drama Instructor Leader Training Program' of the Modern Drama Council was accepted with the decision of Ministry of National Education, Board of Education dated November 18, 2005, and numbered 346. It was agreed that drama lessons should be put into paintings and music departments of fine arts and sports high schools by the decision dated April 5, 2012, and number 20. It was accepted that the drama courses should be put into the program of the private high schools by the decision dated 14 August 2014 and numbered 73 (Morgül, 1999, MEB, 1999).

According to the decision called 'Reorganizing the Teacher Training Programs of Teachers College' of the Council of Higher Education in 1997, the monotype undergraduate program application was stated in educational institutions, and firstly the drama lesson was started in preschool teaching and school teaching programs since 1998-99 within this concept (Kızılçaloğlu, 2005).

Within the context of the works of legal acquits for Europe Higher Education since 2003 and as the result of the studies by the Council of Higher Education, MNE, General Directorate of Primary Education, Board of Education and Teachers College Development Committee, the drama lesson has been started as the required course so as to be started in 2006-2007 in the undergraduate programs of teacher college raise educators for primary and secondary schools.

It is seen when the body of literature is evaluated that the contribution of the drama became a subject about its effects on the teacher candidates study in different departments of the teacher's college in several universities. Some of these studies are expressed in this research chronologically.

Metin (1999) specified that the drama affects the social-emotional developments of children in 56 age groups who attend to first school establishment positively. Okvuran (2003) expressed in his study about the capabilities of the drama teachers that these teachers need to have many skills. According to Karadağ and Çalışkan (2006), using the drama method in lessons provide more permanent learning in comparison with the traditional methods. Kara and Çam (2007) researched in their study contains 74 teacher candidates that the effect of the creative drama procedure in development and learning lesson for being gained the skills such as do and conduct work with a group, start and sustain and control oneself. Hasirc1, Bulut, and Saban (2008) did research to determine the personal and academic earnings of the drama lesson for teacher candidates in primary schools. Sever, Yalçınkaya and Mazman (2009) presented the importance and effects of being used the dramatization methods in social sciences education by considering all sides of the method. According to the findings of Ormanc1 and Ören (2010), the drama lesson that the 
Çakır, T. (2017). The opinions of preschool teacher candidates on vocational and personal achievements from the drama lesson. Journal of Human Sciences, 14(2), 2047-2060. doi:10.14687/jhs.v14i2.4616

students take in school life contributes to their career as well. Tarman and Kuran (2011) conducted research to determine the opinion and attitude of social sciences teacher candidates about the contribution of the drama lesson they took in university for their personal and vocational development. Çetingöz (2012), reviewed the self-efficacy levels of the preschool teacher candidates for using the creative drama method and the relation between these levels and various variables. Saçlı (2013) did research to analyze whether the drama education is effective on the critical thinking abilities and tendencies of gym teacher candidates. Gümüss and İspir (2014) actualized the creative drama-based studio applications with the primary school mathematics teacher candidates. Kesici (2014) conducted a study to reveal how the school teachers teach the drama lesson and the possible difficulties and deficiencies during this lesson. Karadağ (2015) aimed to determine the effect of using creative drama as a method to be gained the democratic values to the teacher candidates. Saylan, Altıntaş, and Kaya (2016) prepared an article to confirm the views of the teacher candidates about using the drama in sciences. Uysal (2016) researched the impact of the drama lesson in gym class on the perceptions of the attendees for the concept of drama

\section{Method}

\section{Research Model}

The descriptive research method from the qualitative analysis techniques allows for systematically reviewing the meanings resultant the experiences of people used in research. That's why this method is used in our study. The qualitative research is a research process use idiocratic procedural traditions to understand and explain a social or personal problem starts with assumptions, a specific worldview, reputed use of a theoretical paradigm (Creswell, 2009). Since this study aims to reveal the results about a particular situation, it is equipped with case study design.

\section{Population and Sample}

The purpose of the sample in qualitative researches is to obtain a particular situation or factor which can clarify and deepen a fact. All attentions focus on to find the convenient sample for collecting data about the subject analyzed. In other words, the relation of the sample with the research object is considered rather than the representation power (İslamoğlu \& Alnıçık, 2013). Therefore, the purposeful sampling technique is followed in this study. The sampling of the research is composed of 62 teacher candidates attend to drama lessons in Preschool Teaching Department of Teachers College of Sakarya University in 2015-2016. Since being the students in teaching practice enables them to apply the learnings of drama lesson into their career, these teacher candidates are aware of the contribution of the lesson. 59 of the attendees are women, 3 of them are men.

\section{Data and Collection}

The semi-structured interview technique is used as the data collection method in this study. The open-ended questions encourage the attendee to respond detailedly (Yıldırım \& Şimşek, 2011). The open-ended interview form created by the investigator at the end of the literature survey for revealing the opinions of the preschool teacher candidates about the contribution of drama lesson to their personal and vocational gains is used as the qualitative data collection tool. It is asked for these teacher candidates to answer in line with their thoughts. The content analysis method helped to analyze the data. The content analysis is defined as a systematic, iterable technique summarizes some of the words of a text by smaller content categories and codifications based on certain principles (Büyüköztürk, Bökeoğlu, \& Şekercioğlu, 2012). 
Çakır, T. (2017). The opinions of preschool teacher candidates on vocational and personal achievements from the drama lesson. Journal of Human Sciences, 14(2), 2047-2060. doi:10.14687/jhs.v14i2.4616

\section{Analysis of Data}

The views of the lecturer teach the drama lesson, and the data obtained from the response of preschool teacher candidates for the semi-structured question formats are shown in this chapter of the study. A part of the data obtained from these answers is expressed as are. The names of the teachers are kept private and coded as TC1, TC2, TC3, TC4, TC5,...

The content analysis solves the answers of the attendees for the questions. The content analysis is analyzing a text detailedly and systematically. The issues in the statements of participants are determined. The close ones from these declarations are grouped, and the themes are created. The themes are entitled according to the expressions they contain (Leedy \& Ormrod, 2005). Confirmed that the result of the research matches with the theoretical framework. This circumstance indicates that the research is reliable (Yıldırım \& Şimşek, 2011).

\section{Findings}

\section{1st Theme: Vocational Gain}

TC1:I am acquainted with the drama, I had so fun, and I learned with pleasure. I learned Empathy Kompati and continual learning. I notice to be more relax by the drama. Now, I can express myself as I like. I notice that I have not known my classmates detailedly. I can make eye contact now.

TC9: I learned critical thinking, to look esthetically and believe in myself. I notice that I have given up to kept somebody at a distance. I also realize that some rules, memorization and the authority prevented my potential till today. I notice that people have quite a change thoughts. I developed on pinning back one's ears. I improved my self-confidence, especially in introduction activity.

TC11: I learned what is the confidence and trust by living thanks to the drama. I have understood the importance of cooperation and being a team. I learned to express myself freely. $I$ notice that I can use the opportunities by learning drama. I also realize that I can spend time with my friends by learning and have fun. I have noticed the life energy of freethinking. I can voice my own thoughts freely. I developed $m y$ creativity more in the free environment when I felt free. My communication gets comfortable.
Communication

Learning to learn

Awareness

Free Thought

Critical Look

Esthetics

Perception

Communication

Awareness

Confidence

Teamwork

Awareness

Free Thought

Creativity 
TC27: I learned that the drama is an irrevocable method that I can use in my personal and vocational life. I learned to perform activities with my friend and the students. I also learned to conduct easy, free and so beneficial activities. I realize that the creativity is so important for the drama and the drama is a perfect education method. I notice that the drama is significant for me to develop myself and career. I improved my creativity. I developed collaborating and orientating. I also improved to have confidence in people around.

TC41: I learned what is drama and how it can be used effectively. I learned to know myself and to achieve to bring my abilities far beyond. I learned to be an individual. I learned that I am a value and produce values as well. I notice that $I$ can do a lot of thing with the drama already now and when I become a teacher. I realize that my communication skills have developed and my confidence increased. My communication, free thinking, understanding abilities and courage enhances. I have understood the value of time and improved to use it better thanks to the drama. Now, I can think more free and creative. I am tolerant now.

TC50: I learned to be different in the society, not a herd person. I learned the drama and how the activities are conducted. I learned the leadership and how I improve my leadership ability. I notice that the drama can achieve easier, more, funny and permanent learnings. I also see the importance of naturality. I realize that the person can think about everything and needs to have an idea as well.

TC62: I learned how a good method the drama is. I learned that funny, permanent, creative education and training could be actualized just be the drama. I found out that responsibility and fulfilling are not easy as I guess as. I notice that every person has different abilities and interests on an individual basis. I realize that the drama and the life become integrated indeed. I can express my thoughts freely. I trust and respect myself and others more. I feel more happy, peaceful and secure now than before.
Communication

Education Method

Teamwork

Value

Confidence

Awareness

Leadership

Individualism

Value

Time management

Creativity

Individualism

Leadership

Creativity

Communication

Awareness

Responsibility

Individualism

Critical Look

Communication 

drama lesson. Journal of Human Sciences, 14(2), 2047-2060. doi:10.14687/jhs.v14i2.4616

In the vocational gain contact, the most commons statements of the preschool teacher candidates are Awareness, Leadership, Individualism, Value, Time Management, and Creativity. A preschool teacher candidate explained her feelings as follows; I learned the drama method and how it can be conducted. I heard how the drama activities could be planned and managed. I realize that my career will be more successful in the drama. I also noticed that I could not develop empathy sufficiently and knew the meaning of empathy as wrong. I perceived my own abilities. I realize that I don't know myself well. I started to evaluate the cases and the situations differently. Now, I can produce more creativity ideas. My self-confidence and the communication enhanced. There are three main areas of the roles which the teacher candidates need to have. These areas are respectively aligned as; organization-planning and teaching approach, Vocational Professionalism and Social skills (Capel, 2001). The codes which are emerged by the words used in analyses match with this situation.

\section{2nd Theme: Personal Gain}

TC2: I learned the drama which I lost so much because I didn't see it until this day. I learned I could be more creator in a free environment. I learned to take the other people on to be creative. I saw that everybody is sorry about the same things, but the effects of the worries vary from person to person. I realize that everybody is pleased by a different thing. I also noticed that I learn better due to the drama. I developed about not to be afraid of acting differently. Now, I think I listen people more consciously who are around me.

TC8: I learned I could do and achieve what I want without any fear by drama. I learned to know and believe myself and trust the others. I realized I have a lot of imperfections. I also noticed that I know anything about the drama. I realized that the drama is a good teaching method. I improved myself about the creative thinking. Now, $\boldsymbol{I}$ can show empathy and communicate and express myself better.

TC23: I learned the difference between dram and dramatization. I discovered the drama immensely contributes to the development of an individual and the children. I learned the importance of the creativity and to prepare a mask quickly and economic. I realized that I could spend original and funny time during the drama activity. $I$ also noticed that the drama is action and communicationbased. I realize that the drama is self-centered and makes the person active. Now, I can understand the feeling of people around me better. I can express myself easily now. I progress about trusting myself and others.
Freedom

Risk-Taking

Respect for Diversity

Listening

Self Confidence

Mutual Trust

Awareness

Communication

Self Confidence

Mutual Trust

Awareness

Have Fun

Communication 
Çakır, T. (2017). The opinions of preschool teacher candidates on vocational and personal achievements from the drama lesson. Journal of Human Sciences, 14(2), 2047-2060. doi:10.14687/jhs.v14i2.4616

TC35: I learned to play-act and be aware of my capabilities by the drama. I learned that to live and deal with people difficult without communication. I learned that I could produce creative ideas by thinking. I learned to look at the issues from a different aspect when I want and think. I realized that out all moves have a meaning indeed.

TC46: I learned that the drama develops, encourages creativity and makes the person think in every respect. I found out that the drama always guides the individual and the attendees for being active. I learned that the drama activities establish natural, relax, free, flexible and funny environments. I realized that the perfect ideas could be created by the friends who I did not expect from. I also noticed to endure, listen and understand. I realize that the cooperation and co-development bring peace and happiness. I made significant progress in my all abilities by means of the drama activities that I have never participated before. I developed my communication skills.

TC52: I learned that the drama contributes for originality, comfort and creativity development more than other techniques. I learned that the communication, confidence, teamwork, tolerance and solidarity actualize easily by the drama. I learned to know myself and my friends and work together. I realized that I am far away from my friends and other people around me. I also noticed that $I$ am lacking in self-reliance and need to develop myself. I saw the losses caused by the herd mentality. I developed myself in creativity and improvisation. Now, I can play-act and express myself better.

TC60: I learned to use my body language effectively when I express my own ideas. I learned that the individual could be oneself when being the herd mentality eliminated. I realized about how I can express myself with my body. I also notice that my communication skills develop gradually. My listening, communication and understanding abilities and self-confidence enhanced. Now, I can use the time efficiently, active and productive. I live free, happy and more prosperous days by planning. I always improve.
Communication

Solution Finding

Creativity

Awareness

Creativity

Communication

Self Confidence

Awareness

Awareness

Self Confidence

Communication

Creativity

Awareness

Communication

Creativity

Self Confidence 
Çakır, T. (2017). The opinions of preschool teacher candidates on vocational and personal achievements from the drama lesson. Journal of Human Sciences, 14(2), 2047-2060. doi:10.14687/jhs.v14i2.4616

In the personal gain contact, the most common expressed statements by the preschool teacher candidates are; Creativity, Communication, Solution Finding, Awareness, Self Confidence, Mutual Trust. A preschool teacher candidate expressed her feelings as follows; I have now developed in interaction with people and feel myself more relax and free. I improved myself to act creatively and also be creative. According to Ömeroğlu, the drama method must be used to increase and develop the qualification of the teacher. Drama contributes to the personal development of the preschool teacher candidates besides being a way that they can use in their classes. Because the drama allows for the person to know and develop oneself and improve the communication skills (Adıgüzel, 2006). Drama enhances the self-reliance and respect; communication and problem-solving competencies. Due to all these features, the drama should be used in each stage of the formal training and ensured the participation of educators of children to the creative drama activities. Drama avails for both the critical and creative thinking (McCaslin, 2006). As is seen above, the drama is a discipline for the teacher candidates use for their personal development besides being a method to use in classes (San, 2006).

\section{Conclusion and Suggestions}

Being given the drama lessons in the post-graduate period is a quite important development. The activities that the teacher candidates use in drama lessons in their post-graduate time can contribute to the learning process in the career (Üstündağ, 2006). It is seen when the qualitative findings obtained from the research are evaluated that the teacher candidates have significant gains regarding vocational and personal by the drama lesson. According to the results obtained, the teachers like the drama lessons when they took in university, and this lesson makes major contributions to their personal life and careers.

It is confirmed at the end of this research that the attendees and the preschool teacher candidates notice the importance of the drama lesson at the right time and afterward as well. It is seen that the personal and vocational gains such as communication skills, verbal ability, empathy and social ability, body language, self-reliance, problem-solving, creativity, cognitive skills, awareness, learning by experience, psychomotor skills, taking responsibility skill are the qualifications that wanted to be gained by the students.

It can be mentioned about the candidates can feel ready for their jobs by these gains and by noticing the imperfections such as awareness, problem-solving, critical look, communication, and self-reliance.

This research is similar to the findings of studies of McCaslin (2000); Okvuran (2003); Dalbudak (2006); Kandır (2006); Önder (2007); Ormanc1 and Ören (2010); Tarman and Kuran (2011).

The results of this research match with other studies by different investigators. When the contribution of the drama lesson manifests itself, the gains of the lesson can be researched by the lecturers, teacher candidates, and the preschool teachers to carry these gains a step further.

Different studies that evaluate how the preschool teachers use this method and their opinions should be actualized. The results of these new studies can be helpful for improving the postgraduate academic programs and in-service drama educations. Awareness and the sensibility training about the drama education should be conducted for the parents who are the other stakeholders in the preschool teaching. 
Çakır, T. (2017). The opinions of preschool teacher candidates on vocational and personal achievements from the drama lesson. Journal of Human Sciences, 14(2), 2047-2060. doi:10.14687/jhs.v14i2.4616

\section{References}

Adıg̈̈zel, H. Ö. (1993). Relationship Between Game and Creative Drama. Ankara: Ankara University Institute of Education Sciences Unpublished Master's Thesis.

Adigüzel, H. Ö. (1994). A New Method and A Discipline in Education: creative drama. Educational Sciences Congress Çukurova University, Winter(5), 522-533.

Adigüzel, H. Ö. (2000). Importance and Necessity to Raise the Creative Drama teacher Journal of Education and Life, Winter(5), 17-18.

Adigüzel, H. Ö. (2006). The Concept of Creative Drama, Stages, and Components. Journal of Creative Drama, $1(1)$.

Akyüz, Y. (1994). Since the Turkish Education history to 1993. Kültür College Publishings.

Altıntaş, E., Saylan, A., \& Kaya, H. (2016). Determining the self-efficacies and attitudes of teacher candidates about teaching the sciences by drama method. International Journal of Social Science(49), 419-437.

Aral, N., Kandır, A., \& Yaşar, C. (2002). Preschool Education and Preschool Education Program. İstanbul: YAPA.

Argun, Y. (2012). Creativity and the creativity education in preschool period. Ankara: Anı Publishing.

Aytaş, G. (2008). Activities and Application of Thematic Creative Drama in Turkish Teaching and Creative Drama Theory and Applications. Ankara: Akçağ Publishing.

Ministery ,.C. (1937). New Primary School Curriculum Program İstanbul: Devlet Printing House.

Tarman, B., \& Kuran, B. (2011). Opinion and Attitudes of Social Sciences Teacher Candidates About the contributions of Drama for Their Personal and Vocational Development. Ahmet Keleşoğlu Journal of Teachers College(32), 85-100.

Büyüköztürk, S.., Bökeoğlu, Ö., \& Şekercioğlu, G. (2012). Multi-Variable Statistics SPSS and LISREL Applications for Social Sciences Ankara: Pegem Publishing

Capel, S. L. (2001). Learning to Teach in the Secondary School. London: RoutledgeFalmer.

Creswell, J. W. (2009). Research Design: Qualitative, Quantitative, and Mixed Methods Approaches, 3th Edition. California: SAGE.

Çakır, T. (2003). İstanbul: Controller for Multidimensional Activity Model in Control Activities of Preschool Education Institutions and the Perception and Expectations of the Teachers. İstanbul: Marmara University Institute of Educational Sciences. Unpublished Doctoral Thesis.

Çakır, T., \& Oktay, A. (2004). Controller for Multidimensional Activity Model in Control Activities of Preschool Education Institutions and the Perception and Expectations of the Teachers. International Preschool Teaching Congress.

Çetingöz, D. (2012).. 131-142. The Self-Efficacies of the Preschool Teacher Candidates for Using the Creative Drama. The Journal of Hacettepe Univesity Educational Sciences (42).

Çoruh, S. (1943). Dramatization in Schools. Ankara: Ankara Bookstore.

Dalbudak, Z. (2006). Research about using the drama activities by preschool teachers. Ankara: Ankara University, Institute of Science and Technology, Unpublished Post Graduate Thesis.

Deniz, M. E., \& Erözkan, A. (2016). Psychology Consulting and Guidance Ankara: Maya Academy.

Genç, H. N. (2003). To Gain Meaning the Creative Drama in Education. Hacettepe University, Journal of Teachers College: 24, 196-205.

Gümüş, F., \& İspir, O. (2014) Structuring the efficient learning environments by the drama regarding Primary School Mathematic Teacher Candidates. Journal of Electronic Social Sciences 13(51), 241-254.

Güneysu, S. (1991). Drama in education. Ya-Pa 7. Preschool Education Development Seminar, 84-88.

Hasirc1, Ö. K., Bulut, S., \& Saban, A. İ. (2008). Teacher Candidates' Opinions Regarding Individual and Academic Achievements of Creative Drama Course. Journal of Creative Drama, 3(6), 1-25.

İslamoğlu, A. H., \& Alnıaçı, Ü. (2013). Research Methods in Social Sciences. İstanbul: Beta Publishing.

Kandır, A. (2006). Development of creative drama in the preschool period. E. v. Ömeroğlu, drama in preschool education (s. 29-36). Ankara: Kök Publishing.

Kara, Y., \& Çam, F. (2007). The Impact of Creative Drama Method on Making Some Social Skills. Hacettepe University Journal of Teachers College 32, 145-155.

Karadağ, B. (2015). Being gained the democratic values by the creative drama method in line with the metaphoric perceptions of the classroom teacher candidates. Unpublished Post Graduate Thesis. Sakarya: Sakarya University, Institute of Educational Sciences.

Karadağ, E., \& Çalışkan, N. (2006). Evaluating the attitudes of Primary school First Stage students about the Drama Method. Pamukkale University Journal of Teachers College(19), 45-57.

Karakaya, N. (2007). Drama in primary school and a sample. GÜ, Journal of Gazi Teachers College, Edition 27 , Number 1, 03-139. 
Çakır, T. (2017). The opinions of preschool teacher candidates on vocational and personal achievements from the drama lesson. Journal of Human Sciences, 14(2), 2047-2060. doi:10.14687/jhs.v14i2.4616

Kesici, A. E. (2014). Teacher's opinions about drama lessonAbant İzet Baysal University Journal of Teachers College, 14(2), 186-204.

Kızılçaoğlu, A. (2005) The Criticism and Suggestions About the Restructuring Process in the Teachers College. Journal of Social Sciences 133-140.

Köksal Akyol, A., \& Çiftçibaş1, H. (2004). The Importance of Drama for Raising Preschool Education Teachers and The Drama in Preschool Education. The features of the show leader/teacher. Ankara: Oluşum Publishing.

Levent, T. (1993). Game and Creative Drama Relation. Ankara: Ankara University Institute of Educational Sciences Unpublished Master Thesis.

McCaslin, N. (1984). Creative drama in the primary grades. London: Longman.

McCaslin, N. (1990). Creative Drama in the Classroom. London: Longman.

McCaslin, N. (2006). Creative Drama in the Classroom and Beyond. Pearson.

MNE. (1936). Primary School Program. İstanbul: State Printing House.

MNE. (1948). Primary School Program. National Education Printing House.

MNE. (1962). Primary School Program. National Education Printing House.

MNE. (1968). Primary School Program. National Education Printing House.

MNE. (1993). Preschool education commission report. Ankara: Board of Education, Ministry of National Education. Secretary-General.

MNE. (1999).Drama in Primary School 1 (For Teacher). Ankara: Ministry of National Education State Books.

Metin, G. G. (1999). An examination of the effect of Drama on the social-emotional development of 5-6-year-old children. Istanbul: Marmara University Institute of Educational Sciences Graduate Thesis.

Morgül, M. (1999). Hello to Creative Drama in Education. Ankara: Kök Publishing.

Oktay, A. (1993). Corporate Education and Teacher Training in Preschool.Ankara: T.C. Ministry of National Education General Directorate of Pre-School Education.

Okvuran, A. (2003). Drama Teacher's Qualifications. Ankara University Journal of Educational Sciences, 36(1-2), 81-87.

Ormanc1, Ü., \& Ören, F. Ş. (2010).The opinions of primary school teacher candidates about the usability of the drama in primary education: Sample of Demirci Faculty of Education Ankara university Journal of Educational Sciences, 43(1), 165-191.

Ömeroğlu, E. (2006). Creative drama in the development of the quality of preschool teacher. Ankara: Naturel Publishing.

Önder, A. (2007).Creative drama for living by learning. İstanbul: Epsilon Publishing.

Özdemir, P., \& Üstündağ, T. (2007). Creative Drama Training Program for Famous Scientists in Science and Technology. Primary School Online 6(2), 226-233.

Saçl, F. (2013). Impacts of creative drama education on the critical thinking skills and tendencies of physical education teachers. Unpublished PhD Thesis. Ankara: Hacettepe University Health Sciences Institute

San, İ. (1990). Creative drama in education. Ankara University Journal of Educational Sciences, 23(2), 573-582.

San, İ. (1991). Creative Drama - Educational Dimensions. H. Ö. Adıgüzel içinde, Creative Drama. Ankara: Naturel Publishing.

San, İ. (1996). Yaratıcılığı geliştiren bir yöntem ve yaratıcı bireyi yetiştiren bir disiplin: Eğitsel yaratıcı. Yeni Türkiye Dergisi(7), 148-160.

San, İ. (2006). Tiyatroya Rağmen Yaratıc1 Drama. Yaratıc1 Drama Dergisi, 1(1), 6-12.

Sever, R., Yalçınkaya, E., \& Mazman, F. (2009). An Effective Teaching Method in Teaching Social Studies:Dramatization. Atatürk University Journal of Social Sciences Institute, 13(1), 155-166.

T.R. Higher Education Board. (2007). Teachers College Teacher Training Undergraduate Programs. Ankara: Higher Education Institution Publishing.

Uysal, B. (2016). An Evaluation of Drama Perceptions of Physical Education Teachers Candidates. Mustafa Kemal University Journal of Social Sciences Institute, 13(35), 19-33.

Üstündağ, T. (2006). Diary of Creative Drama Teacher. Ankara: Pegem Akademi Yayıncilik

Vural, R. A., \& Somers, J. W. (2012). Drama in Primary Education for Humanist Primary Education Programs: Theory and Practice. Ankara: Pegem Academy.

Yavuzer, H. (2013). The first 6 years of your child with physical, mental and social development. İstanbul: Remzi Bookstore.

Yıldırım, A., \& Şimşek, H. (2011). Qualitative research methods in the social sciences. Ankara: Seçkin Publishing.

Zembat, R. (1994).Administrator characteristics in pre-school education institutions. Marmara University Atatürk Teachers College Journal of Education Units (6), 313-323. 